\title{
SUSTAINABLE DEVELOPMENT IN A CONSTRUCTION RELATED CURRICULUM - QUANTITY SURVEYING STUDENTS' PERSPECTIVE
}

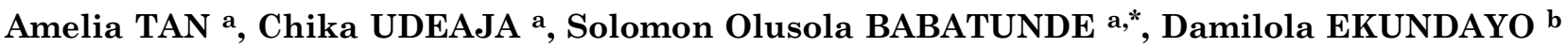 \\ ${ }^{a}$ Faculty of Engineering and Environment, Northumbria University, Newcastle upon Tyne NE1 8ST, UK \\ ${ }^{b}$ Faculty of Technology, Design \& Environment, Oxford Brookes University, Gipsy Lane, Oxford OX3 OBP, UK
}

Received 25 June 2015; accepted 11 February 2016

\begin{abstract}
Higher education institutions (HEIs) across the globe are increasingly aware of the need to integrate sustainability education within the curricula. This triggered a number of studies were conducted by earlier researchers in embedding sustainability education within the curricula. Thus, studies have been carried out to evaluate how students perceived sustainable development in their curricula, particularly in engineering and other related courses. Few of these studies were conducted in built environment, most especially in quantity surveying. It is against this backdrop that necessitated this study. The purpose of this study is to establish the extent in which sustainable development is embedded in the construction related curriculum using the perception of quantity surveying students. The study adopted literature review, documentary reports among others as a secondary method of data collection. Primary data were collected through online questionnaire survey administered to 330 randomly selected quantity surveying students in a university in the UK. Out of which 87 completed questionnaires were retrieved and suitable for the analysis. The quantitative data obtained were analysed using mean score, one-way analysis of variance (ANOVA) and regression analysis. The study identified 46 sustainability topics, which were grouped into 6 categories (i.e. A-F). Based on these categories, the study found that students' knowledge level on sustainability was a little above 'basic/ limited knowledge with the overall mean score value of 2.38 on a 4 - point Likert scale. The study further revealed that the students placed high importance on sustainability education, despite their knowledge level were found lower. The study findings would be used to establish the extent of sustainability within the curriculum in the quantity surveying programme. Also, this study would be of great value to academic staff and University management boards to develop a framework for incorporating sustainability education in the curriculum.
\end{abstract}

KEYWORDS: Quantity surveying; Sustainability; Sustainable development; Construction industry; Education; Students and stakeholders

\section{INTRODUCTION}

Climate change, degradation of ecological balance, and diminution of natural resources are visible signs that the earth's bearing capacity is not infinite (Abdul-Wahab et al. 2003). In tackling these issues, the governments around the world have been very keen on promoting the concept of sustainable development (SD), which seeks to meet human needs while ensuring the sustainability of natural resources and the environment, so that these needs can be met not only in the present but also for the future generations (World Commission on Environment and Development 1987). In the UK, the SD has drawn so much interest since the

* Corresponding author. E-mail: sobabatunde80@gmail.com field first attracted attention in the 1980s. Achieving progress towards sustainability is critical to the future well-being of society; this has long been recognised by the government (Seyfang, Smith 2007; Cartlidge 2011). They have placed SD as a major objective both at a national and local sphere of influence and activity. Parallel to the SD trend in the UK, there is an increasing demand, in the construction sector, to understand sustainable design and construction practices (BERR 2008). This demand is driven by the realization of the need for sustainable practices that not only help the environment but that can also improve economic profitability and improve the competitiveness of the construction organisations (Revell, Blackburn 2007; Tan et al. 2011). 
It is clear that SD is increasingly high up on the agenda of construction industry because government, clients, employers and related professional body are raising their standards in demanding for sustainability literate graduates (Murray, Cotgrave 2007; Darwish, Agnello 2009; Iyer-Raniga et al. 2010; Ekundayo et al. 2011; Lozano et al. 2013). It is thus crucial that students' education embraces and incorporate sustainability within the curriculum. There are many researchers in this area who believe that the sustainability agenda and construction related activities are intrinsically linked (Walton, Galea 2005; Cotgrave, Alkhaddar 2006; Hayles, Holdsworth 2008; Theron 2010). The rationale, therefore, for embedding sustainability issues within the construction curriculum is a powerful and imperative one. However, the responses from the colleges and universities that provide education for the construction professional are still patchy and minimal. It is increasingly recognised that the curriculum should incorporate sustainability or green issues and produce graduates that are confident of taking care of the environment without damaging it for future users. Hayles and Holdsworth (2008) argued that the 21st Century is seen as the time for the UK universities to embrace new working practices. This is especially important if the educational system is to continue to be competitive and also meet the needs of its increasingly demanding stakeholders.

Studying at higher education institutions (HEIs) is a basic route of knowledge and skills enhancement for built environment professionals. For instance, as the construction industry now moves into a new era where sustainability issues are required to be integrated into construction practices, the construction related professionals such as the quantity surveyors are expected to broaden and enhance their knowledge, skills and competencies to promote sustainability. This is not without challenges. For instance, literature has indicated the common barrier of SD is the lack of knowledge and skills of the professionals (Lewis et al. 2005; Dixon et al. 2008). Embedding sustainability in the Built Environment (BE) education is very important to address the issues in the industry, and research on effective pedagogies has been carried out to push for and improve sustainability education (Lewis et al. 2005; Iyer-Raniga et al. 2010; Niu et al. 2010; Cotgrave, Kokkarinen 2011). In particular, perceptions of students on sustainability are regarded by sev- eral researchers as one of the effective education tools for improving sustainability education. IyerRaniga et al. (2010) argued that students' perceptions are important to understanding whether the intended knowledge is delivered at the right level. In the general built environment education sector, few researchers (see Cowling et al. 2007; Iyer-Raniga et al. 2010; Cotgrave, Kokkarinen 2011) had explored students' perceptions to reorient education to address sustainability. Existing studies in Quantity Surveying (QS) curriculum (see Perera, Pearson 2011; Ekundayo et al. 2011; Perera et al. 2013; Lee et al. 2013) have focused on QS competencies and their application in the delivery of $\mathrm{QS}$ degree programmes, and QS early training. Few of these studies that examined sustainability in QS curriculum (see Ekundayo et al. 2011) developed a sustainability framework relevant to QS degree programme. Despite these previous studies, there is a paucity of research investigating quantity surveying students' perceptions of sustainability. This study aims to fill this gap by establishing the extent in which sustainable development is embedded in the construction related curriculum using the perception of quantity surveying students. Achieving this is fundamental to understand whether the intended knowledge is delivered at the right level. Thus, this study becomes imperative to address the research question - "how students perceived sustainable development in their curricula in the built environment disciplines, most especially in quantity surveying?" In this respect, this study was guided by the following derived objectives:

- Empirically investigate the awareness and attitudes of QS students have towards sustainable development.

- Assess the level of QS students' knowledge, and identify knowledge gaps in QS - relevant sustainability knowledge areas.

- Explore the students' opinions towards sustainability education within the current QS curriculum.

It is believed that this study would be of great value to academic staff and University management boards to develop a framework for incorporating sustainability education in the curriculum. It is further anticipated that this study will contribute to improving the understanding of the knowledge of students on sustainable development, and positively influence their attitudes and behaviours when they graduate. 


\section{LITERATURE REVIEW}

\subsection{Sustainable development and the construction industry}

Since the publication of the Brundtland Report (World Commission on Environment and Development 1987), sustainability has become an important topic in many industries both in the UK and globally. In the construction sector, the recognition of the importance of the construction industry for sustainability through agendas such as sustainable development (SD), sustainable construction, sustainable building among others has gained widespread momentum. Ganah et al. (2008) identified that construction activities represent complex activities that place a significant strain on the wider environment and also one of the major factors that determine the sustainability of a community. Ganah et al. (2008) further stated that buildings have a major environment impact over their entire lifecycle from construction to the demolition of the building structure. The relationship between the construction and SD is one which has been extensively explored and is well documented in research work (see Hill, Bowen 1997; Bourdeau 1999; Gilham 2001; Kibert 2007; Edum-Fotwe, Price 2009) among others. Kibert (2007) recognised the contribution of the construction sector to SD agenda could be immense. Boardman (2007) estimated that the construction in its widest sense is responsible for $40 \%$ of $\mathrm{CO} 2$ emission, as well as $40 \%$ of all energy used. The industry faces ever-increasing problems in managing and dynamically responding to changes in the environment (climate changes) and the needs of their clients, particularly in the building sector (Meikle 2008). Moreover, the SD principles are increasingly seen not just as an issue of SD but as a valuable argument to address the technical process that determines the likely performance of a building or construction project. This emerging role presents new and considerable challenges for construction or building projects during its whole life. To attain the goals of green construction requires that the industry intensifies its efforts in embedding sustainability issues within the construction field.

There has been several industry and UK government attempts to encourage SD and, in particular, sustainable construction. Such attempts include the development of various sustainability assessment techniques in buildings such as the code for sustainable homes (CfSH), Building Research Establishment Environmental Assessment Method (BREEAM), and the Green Guide.
Udeaja et al. (2013) added that initiatives such as green supply chain management (GSCM), green building, zero carbon homes, and carbon counting have been explored recently and they are all signs of growing recognition of the need for embedding $\mathrm{SD}$ in the construction field. Furthermore, the UK government have taken considerable measures to promote sustainability in the construction industry by developing a range of environmental tax, levy, regulations, incentives, and formalised methods of managing carbon (Pellegrini-Masini et al. 2010; Monahan, Powell 2011). It is clear why the construction industry must respond accordingly and focus its attention on developing sustainable buildings which are economically viable, socially acceptable and environmentally friendly. In particular, there continues to be greater emphasis on sustainable buildings with less impact on the environment (RICS 2012). Coupled with this is the increasing need for the judicious use of the irreplaceable, dwindling natural resources (Emmanuel, Baker 2012). Construction industry for a long time has worked tirelessly in achieving safe and SD in a cost effective, environmentally protective and socially responsible manner. The construction professionals of the future will need to be well equipped to account for all aspects of the construction given their broad roles from design to deconstruction of the built environment. Consequently, the construction industry must incorporate principles of sustainability wholeheartedly into each of its projects, so that its contribution to SD will be influential and finally beneficial to both human and economic developments. This means that the construction industry needs professionals who through education systems are trained and mindful of the SD issues and have the knowledge and competency to participate and contribute to the industry that can sustain rather than degrade the environment, economy and society in the long run.

\subsection{Importance of embedding sustainability in education}

The importance of the construction sector in addressing the issue of sustainable development (SD) is undeniable. The Brundtland report defines sustainable development (SD) as "development that meets the needs of the present without compromising the ability of future generations to meet their own needs" (World Commission on Environment and Development 1987). Also, SD seeks to address the balance between the environment, economy and 
society without compromising the need for future generation (Ganah et al. 2008). The three elements in the concept of SD - the environment, economy and society, are known as the "three pillars" of SD. Thus, it is imperative that the built environment (BE) in general embed sustainability principles within the educational and training of the future graduates to ensure that they possess appropriate knowledge, skills and value sets (Lewis et al. 2005; Murray, Cotgrave 2007; Darwish, Agnello 2009). Further, Darwish and Agnello (2009) emphasised the need to instil graduates with up-to-date knowledge and skills so that that they will be able to manage any uncertainties that may arise and also make a judgement on the available evidence in built environmental design and construction. Cortese (2003) stated that the higher education institutions (HEI) have "profound moral responsibility to increase the awareness, knowledge, skills and values needed to create sustainable future". HEIs are the most important primary sources of knowledge which are capable of enforcing and changing the attitudes, behaviours and practices of the professionals to embrace and promote SD. The argument for embedding sustainability in education is further reinforced by several initiatives around the world. For example, the Earth Summit in 1992 gave high priority in its Agenda 21 to the role of education in promoting sustainable development and improving the capacity of the people to address sustainable development issues (Grubb et al. 1993). Lozano et al. (2013) identified that the summit focused on the process of orienting and re-orienting education in order to foster values and attitudes of respect for the environment. Other initiative includes the 2002 Johannesburg Summit that has broadened the vision of SD and re-affirmed the educational objectives within the millennium development goals (MDG 2013). There is evidence that some progress in sustainability education has been made in the last decade, but much more remains to be done.

Despite the fact that progress has been made in incorporating sustainability education in curriculum, the extant literature have shown and revealed issues of irregular and inefficient engagement of the HEIs in delivering adequate competencies, knowledge, skills and attitudes required for achieving the goals of sustainability in the built environment (Cotgrave, Alkhaddar 2006; Ganah et al. 2008; Cotgrave, Kokkarinen 2010). The HEIs are facing challenges in embedding effective sustainability education into the curriculum. Hence, what is required is a suitable pedagogic strategy for SD education. Ekundayo et al. (2011) identified pedagogical strategy as an approach that collaborates with and gathers input from the industry, academia, students and professional bodies in order to reorient sustainability education.

\subsection{Previous studies on students' perceptions of SD}

Students' perceptions have long been recognised by the academia as one of the most important indicators of the effectiveness of education and a tool for overcoming shortcomings in education. Their perceptions serve as an effective yardstick for judging the progress, as well as determining methods and identifying areas for improvement in teaching and learning. Therefore, selected studies on students' perceptions of SD by earlier researchers are presented in Table 1.

It is evident from Table 1 that studies on students' perceptions of SD available, but very few of these studies were conducted in the built environment, especially from quantity surveying students' perceptions of sustainability in their curriculum. Assessing students' perceptions of sustainability should be continuous to constantly evaluate and improve curricula in higher education institutions (HEIs). This would enable the educational system to be competitive and meet the needs of its ever demanding stakeholders. It is on this premise that this study becomes imperative with a view to investigating how extent quantity surveying students know about sustainable development and determine the possible implications for their curriculum. This would be of great value to academic staff and University management boards to have a better understanding of the students' knowledge level on sustainability.

\section{RESEARCH METHODOLOGY}

This study adopted literature review, documentary reports, and questionnaire survey. A comprehensive literature review was conducted to identify sustainability topics. Thus, few previous research has established the content of sustainability education within the curriculum and mapped sustainability education within QS degree programmes by evaluating academic and industry perception (Ekundayo et al. 2011; Perera, Pearson 2011). This study, therefore, adopted the identified 46 sustainability topics in the sustainability education framework developed by Ekundayo et al. (2011) in the UK. The rationale for adopting these 46 sustainability topics was that it has been used to 
Table 1. Students perceptions to reorient education to address sustainability

\begin{tabular}{|c|c|c|c|c|c|}
\hline $\begin{array}{l}\text { Author and } \\
\text { year }\end{array}$ & Focus & $\begin{array}{l}\text { Students } \\
\text { discipline }\end{array}$ & Study area & Methodology & Findings \\
\hline $\begin{array}{l}\text { Iyer-Raniga } \\
\text { et al. }(2010)\end{array}$ & $\begin{array}{l}\text { Investigating \& } \\
\text { comparing the } \\
\text { level of sustain- } \\
\text { ability under- } \\
\text { standing among } \\
\text { graduating } \\
\text { students }\end{array}$ & $\begin{array}{l}\text { Property, } \\
\text { Construc- } \\
\text { tion \& Pro- } \\
\text { ject Manage- } \\
\text { ment }\end{array}$ & $\begin{array}{l}\text { Singapore } \\
\text { RMIT \& } \\
\text { Melbourne RMIT }\end{array}$ & $\begin{array}{l}\text { Questionnaire } \\
\text { survey }\end{array}$ & $\begin{array}{l}\text { No significant differences in the per- } \\
\text { ceptions, knowledge, and understand- } \\
\text { ing of sustainability issue amongst } \\
\text { Melbourne and Singapore students. } \\
\text { The authors advocated for a new de- } \\
\text { sign of higher education construction } \\
\text { curricula that contains sustainability } \\
\text { in a broader context. }\end{array}$ \\
\hline
\end{tabular}

\begin{tabular}{|c|c|}
\hline $\begin{array}{l}\text { Cotgrave } \\
\text { and } \\
\text { Alkhaddar } \\
(2006)\end{array}$ & $\begin{array}{l}\text { Developing cur- } \\
\text { riculum that } \\
\text { promoted sus- } \\
\text { tainability }\end{array}$ \\
\hline $\begin{array}{l}\text { Cotgrave } \\
\text { and } \\
\text { Kokkarinen } \\
(2011)\end{array}$ & $\begin{array}{l}\text { Testing stu- } \\
\text { dents' percep- } \\
\text { tions and skills } \\
\text { on sustain- } \\
\text { ability after } \\
\text { developing new } \\
\text { curriculum }\end{array}$ \\
\hline $\begin{array}{l}\text { Cowling } \\
\text { et al. }(2007)\end{array}$ & $\begin{array}{l}\text { Exploring } \\
\text { sustainability } \\
\text { perceptions of } \\
\text { students over } \\
\text { time }\end{array}$ \\
\hline $\begin{array}{l}\text { Azapagie } \\
\text { et al. }(2005)\end{array}$ & $\begin{array}{l}\text { Exploring un- } \\
\text { dergraduate } \\
\text { students' per- } \\
\text { ceptions of SD }\end{array}$ \\
\hline
\end{tabular}

Hanning et al. (2012)

Students' perceptions on SD

Kingston
Univer-
sity School
of Surveying
(KUSS)
Engineering

Engineering 21 Universities across the globe participated in the survey- 2 in Australia, 1 in Brazil, 1 in France, 1 in Germany, 1 in Italy, 1 in Sweden, 1 in Thailand, 2 in the USA, 2 in Vietnam, and 9 in the UK

Engineering Chalmers University of Technology, Sweden and Conlon (2012)

Final year students' percep-

Kagawa (2007)

Students' per-
Engineering

Dublin Institute of Technology, Ireland

All faculties

Plymouth University, UK
Literature review, New curriculum was developed to acQuestionnaire sur- commodate sustainability. vey $\&$ Interviews

Questionnaire survey

Significant changes of students' towards sustainability.

Questionnaire survey

Questionnaire survey

Course document- It was found that industry demands a ed text analysis, broader range of competencies in SD Questionnaire sur- amongst engineers in general than vey, Interviews, and Focus group discussion

Questionnaire survey

Online questionnaire survey

Students perceived environmental aspect of sustainability as the most important of sustainable development (SD).

Low understanding of SD. However, strong knowledge of environmental aspect but limited knowledge of social and economic aspects of SD.

Identified that the students believed that SD is important for engineers but the students found it difficult in making a direct link between the theory of $\mathrm{SD}$ and engineering practice.

The authors suggested new engineering curriculum with a view to addressing identified challenges among engineering students.

what is currently provided.

It found that there were knowledge gaps in terms of society aspect. Identified the causes of knowledge gaps.

Identified that students' perceptions were strong towards environmental
Nicolaou tions about SD ceptions of SD aspect.

Significant gaps existing in the knowledge of social and economic aspects of SD.

Suggested new curriculum development to address sustainability in a holistic manner.

Students' atti- First and the Universities

Drayson tudes and skills for SD

third year students in all faculties
A two-phase

across the UK

methodology was conducted: Deskbased research i.e. reviews of existing policy-based research, and online questionnaire survey

Identified that over eight in every ten students were consistently believed that SD should be actively incorporated and promoted by universities.

Identified that over two-thirds of students believed that SD should be covered by their universities courses. Identified that over $60 \%$ of students want to learn more about SD.

Identified that students were interested in SD and there is potential for further enhancing sustainability learning. 
capture the perceptions of academic staff in the universities and industry professionals in the UK. The sustainability education framework that contained the identified 46 sustainability topics is presented in Figure 1.

As shown in Figure 1, the identified 46 sustainability topics were grouped into 6 categories (i.e. A-F). Thus, these 46 sustainability topics were incorporated to design a questionnaire survey. A quantitative method was used to evaluate students' knowledge and perceptions of the identified 46 sustainability topics, due to its suitability for large sample size and its ability to produce precise and generalisable statistical findings. Also, quantitative method has been widely used in similar studies to capture students' knowledge and perception of curriculum and to delve into their awareness and satisfaction of the same (see Azapagic et al. 2005; Cowling et al. 2007; Kagawa 2007; Cotgrave, Kokkarinen 2011; Nicolaou, Conlon 2012; Watson

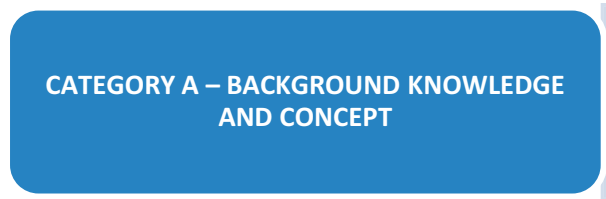

\section{- Sustainable development overview and principles \\ - Climate change and global warming issues \\ - Impact of the construction industry on the environment \\ - Sustainable construction concept \\ - Role of QS in sustainable development}

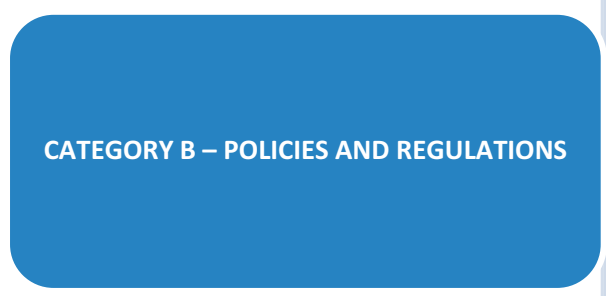

- Changes to Building regulation, e.g. Part L (energy efficiency) and Part F (means of ventilation)

- Code for Sustainable Homes

- Energy Performance Certificate (EPC)

- The Kyoto protocol

- Relevant EU Directives such as the EU climate policy, EU ETS, etc

- Climate Change Act

- Sustainable Construction Strategy

- Sustainable Procurement Action Plan

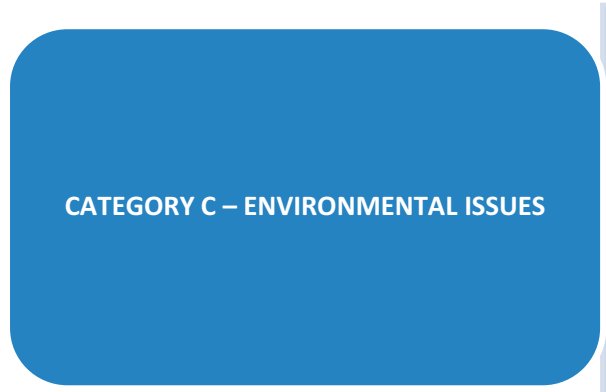

- Protecting and enhancing the built and natural environments

- Environmental Impact Assessments (EIA)

- Environmental Management Systems: ISO 14001

- Environmental Assessment Methods: BREEAM, LEED, Green Star

- Reducing energy consumption, that is, emitted and embodied

- Reducing greenhouse emission such as methane, carbon, nitrous oxide and refrigerant gases

- Carbon Agenda (Carbon footprinting, Zero Carbon, Retrofit)

- Waste reduction principles (recycling, reduction, reuse, effective design) - Brownfield development

- Natural resources, renewable and non-renewable materials

- Water usage and Sustainable Transportation Plan

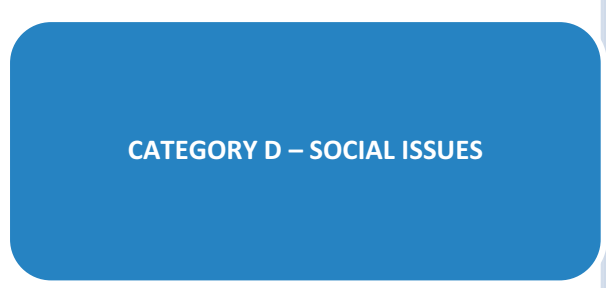

- Corporate Social Responsibility (CSR)

-Ethical issues such as ethical sourcing of materials and labour, for instance

- Equity and social justice

- Community development and social inclusion - Health \& safety

- Employment, training and education

- Social assessment methods (e.g. Design Quality Indicators, KPIs and benchmarking, etc)

- Cost Benefit Analysis (i.e. impact of human factors on the community)

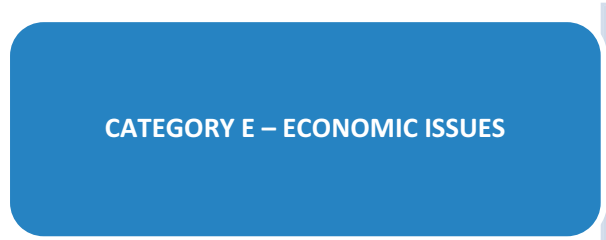

- Cost planning and management

- Value management or engineering (cost of alternative materials and designs)

- Sustainable procurement strategies - Feasibility studies

-Whole-life appraisal/ Life cycle costing

- Financial incentives (such as subsidies, climate change level, aggregate tax, carbon credit, Brownfield land tax, etc)

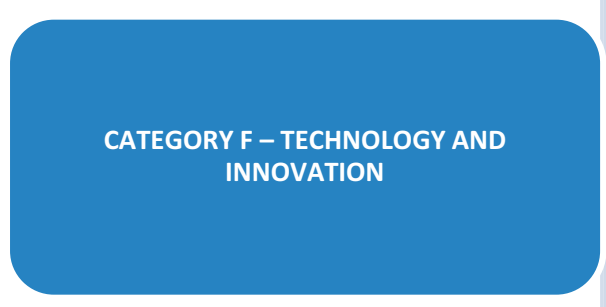

- Renewable energy technologies (Photovoltaic, Wind Turbine, Geothermal, Biomass, etc)

- Green Building Materials

- Rain water harvesting and Grey water collection systems

- Professional and management software packages such as BIM, etc

- Modern methods of construction: offsite production, use of precast material, lean construction, etc

- Passive design methods such as day lighting, intelligent facades, carbon storage and offsetting, etc

- Supply chain management

- Effective information control and management (using e-business)

Fig. 1. Sustainability framework relevant to QS degree programme (adapted from Ekundayo et al. 2011) 
et al. 2013). An online questionnaire survey was conducted to allow a large quantity of samples to be collected efficiently and within available resources. The online questionnaire survey adopted the design used by Azapagic et al. (2005) for engineering students but with modifications to suit this study. The target population for this study is quantity surveying (QS) students comprised both full-time and part-time undergraduate students in a University in the UK. The full-time course is 3 years, and the part-time course follows a similar study pattern to full-time but it takes a longer time of 5 years to complete the degree. Therefore, 330 QS students at the undergraduate level of the study were randomly selected for this study in an RICS accredited University in the North East of the UK. The reason for selecting a University is that this study is a follow-up of research conducted by Ekundayo et al. (2011) in which a sustainability framework relevant to QS degree programme is developed from academic staff in a university and industry professionals' perspectives without considering the perceptions of QS students of that university. It against this background that this study considered the QS students of that university with a view to capturing their perceptions on knowledge levels of sustainability topics already identified by Ekundayo et al. (2011). Prior to data collection, a pretesting study was initially undertaken to test the validity of the questionnaire. The pretesting was conducted with a total of 8 final year undergraduate students and slight alterations were made based on the feedback. A minor issue arose following the pretesting concerning whether the definitions of some terms be defined and explained in the survey. In the end, definitions of some terms were included in the cover email. Furthermore, a reliability test using Statistical Package for the Social Sciences (SPSS) was conducted on the questionnaire. The result indicated the reliability coefficient value of Cronbach's alpha 0.851 signifying that the questionnaire used was significantly reliable and indicates evidence of internal consistency (see George, Mallery 2003). Thus, a total of 330 questionnaires were administered, out of which 87 representing $26.36 \%$ were completed and suitable for the analysis. The effective response rate of $26.36 \%$ was slightly high compared to similar earlier studies. For instance, Lee et al. (2013) achieved a response rate of $10 \%$ when administered questionnaires to quantity surveying graduates in their early careers in the UK. Also, based on Bartlett et al. (2001) calculation to determine an appropriate sample size in survey research for a population exceeding 300 is 85 . Therefore, the received response of 87 satisfies this requirement. The questionnaire for this study was divided into four main sections aiming to capture students' demographic data; their level of awareness of sustainable development; their knowledge in QS-relevant sustainability topics; and their perception of sustainability education within the QS curriculum. A pilot study was initially undertaken to test the validity of the questionnaire. Respondents were asked to rank their answers on a 4-point Likert scale with 4 being the highest of the rating. Data collected were analysed using both descriptive and inferential statistics. Such as percentiles, mean item score (MIS), one-way analysis of variance (ANOVA) and regression statistics. MIS was used to establish the relative level of knowledge of the students and the perceived importance of the sustainability topics. MIS was used to rank the collected data to get the average of the obtained variables. Percentiles, that is, ratios multiplied by 100 were also used in rating a number of factors according to the degree of occurrence attached to them. The higher the percentage rating, the higher the importance or significance attached to such factors. The essence of percentile is to allocate a value between $0-100$ to a factor (100 being the highest possible value) using factor size and total size. The formula is; $\mathrm{P}=\mathrm{n}^{*} 100 / \mathrm{N}$, where $\mathrm{P}$ is the percentage of the factor, $\mathrm{n}$ is the size of the factor in consideration and $\mathrm{N}$ is the total size of the population. Mean item score (MIS) was used to analyse the Likertscale data and is calculated using the formula as follows:

$$
M I S=\frac{\sum \mathrm{n}_{1} \mathrm{k}_{1}}{\sum \mathrm{N}}=\frac{4 \mathrm{n}_{4}+3 \mathrm{n}_{3}+2 \mathrm{n}_{2}+1 \mathrm{n}_{1}+0 \mathrm{n}_{0}}{\mathrm{~N}_{4}+\mathrm{N}_{3}+\mathrm{N}_{2}+\mathrm{N}_{1}+\mathrm{N}_{0}},
$$

where: $M I S=$ Mean item score; $\sum \mathrm{N}=$ Total number of respondents; $\mathrm{N}_{4}=$ the number of respondents that choose 4 , etc.; $0-4=$ the various marks for the ranking of the factors as applicable in each case.

One-way analysis of variance (ANOVA) test was used to test the difference in the level of sustainability knowledge of students in the different years of study. The test was undertaken at $95 \%$ confidence level, that is, the level of significance is $5 \%$. Once the significance of relationship was established, the effect size measure for ANOVA, also known as "eta squared $\left(\eta^{2}\right)$ ", was later used to test how large the differences are, using the formula:

$$
\eta^{2}=\frac{\text { Sum of squares for treatments }}{\text { Total sum of squares }} \text {. }
$$

The results generated from the "equation 2" above were then interpreted using Cohen's 
guideline of $\eta^{2}$ value, where: $0-0.1$ is a weak effect; $0.1-0.3$ is a modest effect; $0.3-0.5$ is a moderate effect; and $>0.5$ is a strong effect. In addition, regression statistics was used to test the relationship between the level of knowledge of students and their year of study. Similarly, its significance was determined by 0.05 level in $p$-value. $R$-squared $\left(R^{2}\right)$ value was used for the regression test to determine the strength of the relationship between the variables and then interpreted as follow, where: $<0.1$ is a poor fit; $0.1-0.3$ is a modest fit; $0.3-0.5$ is a moderate fit, and $>0.5$ is a strong fit.

\section{FINDINGS AND DISCUSSION}

Table 2 shows the distribution of questionnaire and demographic characteristics of respondents. The table indicates a total of 330 questionnaires administered, out of which 87 questionnaires were retrieved representing $26.36 \%$. Table 2 further reveals the breakdown of respondents to include gender, age, origin, mode of study, and level of study. It can be seen from Table 2 that 57 of the respondents are male representing $66 \%$ while 30 of the respondents are female representing 34\%. The age of respondents reveal that $86 \%$ of the respondents are between the age of 18 and 25 years, $9 \%$ are between the ages of $26-35$ years, and 5\% are between the ages of 36-45 years. Also, QS undergraduate programme is either studied as BSc

Table 2. Total and breakdown of responses according to different variables

\begin{tabular}{llll}
\hline \multicolumn{2}{l}{ Demographic characteristics } & Number & $\begin{array}{l}\text { Percentage } \\
(\%)\end{array}$ \\
\hline Total number of respondents & 87 & 100 \\
\hline Gender & Male & 57 & 66 \\
& Female & 30 & 34 \\
Age Group & 17 and under & 0 & 0 \\
& $18-25$ & 75 & 86 \\
& 26-35 & 8 & 9 \\
& $36-45$ & 4 & 5 \\
& $46-55$ & 0 & 0 \\
Origin & 56-65 & 0 & 0 \\
Mode of & Developed countries & 56 & 64 \\
study & Feveloping countries & 31 & 36 \\
& Part-time & 78 & 90 \\
Level of & Level 4 & & \\
study & & 9 & 10 \\
& Level 5 & 11 & 13 \\
& Level 6 & 37 & 43 \\
\hline
\end{tabular}

(Hons) 3 years full-time or 4 years sandwich or as BSc (Hons) part time for 5 years in the UK universities. Therefore, as shown in Table 2, the respondents' mode of study indicates that $90 \%$ of the respondents are full-time students and $10 \%$ are part-time students. Also, the respondents' level of the study reveals that $13 \%$ are in level 4 (i.e. the first year in the university), $43 \%$ are in level 5 (second year in the university), and $44 \%$ are in level 6 (final year in the university). It can be seen that all the respondents are undergraduate. Also, most of the respondents are at higher levels (see Table 2 for details). Based on the respondents' age, mode of study, and level of study has been described afford the respondents to give accurate and reliable information.

\subsection{Students' knowledge level on sustainability}

This is the second section of the questionnaire, respondents were asked to indicate their understanding in all the 46 sustainability topics in the sustainability education framework (see Fig. 1 for details). Therefore, Figure 2 indicates the mean item score (MIS) results of students (respondents) knowledge level on 46 sustainability topics, which were grouped into 6 categories (A-F) with their components. These include: Category A Background Knowledge and Concept; Category B - Policies and Regulations; Category C - Environmental Issues; Category D - Social Issues; Category E - Economic Issues; and Category F Technology and Innovation with their MIS values of $2.64 ; 1.99 ; 2.39 ; 2.15 ; 2.49$; and 2.59 respectively. It can be deduced that students (respondents) appeared to have the most knowledge in Category A - Background Knowledge and Concept (2.64) and the least knowledge in Category B - Policies and Regulations (1.99) (see Fig. 2 for details).

This result is in contrast with few previous studies. For instance, Kagawa (2007) and Hanning et al. (2012) discovered students' understanding of sustainability was inclined towards environmental aspects. This difference could be attributed to the nature of the programme being studied. Whilst understanding of the technical aspects of sustainability may be critical in engineering degree programmes. Thus, the overall background and concept of sustainability may be more important in quantity surveying programmes. As shown in Figure 2 the MIS values for the 6 main categories ranging from 1.99 to 2.64 , also, the overall MIS value of 2.38 (out of 4) representing $59.50 \%$ 


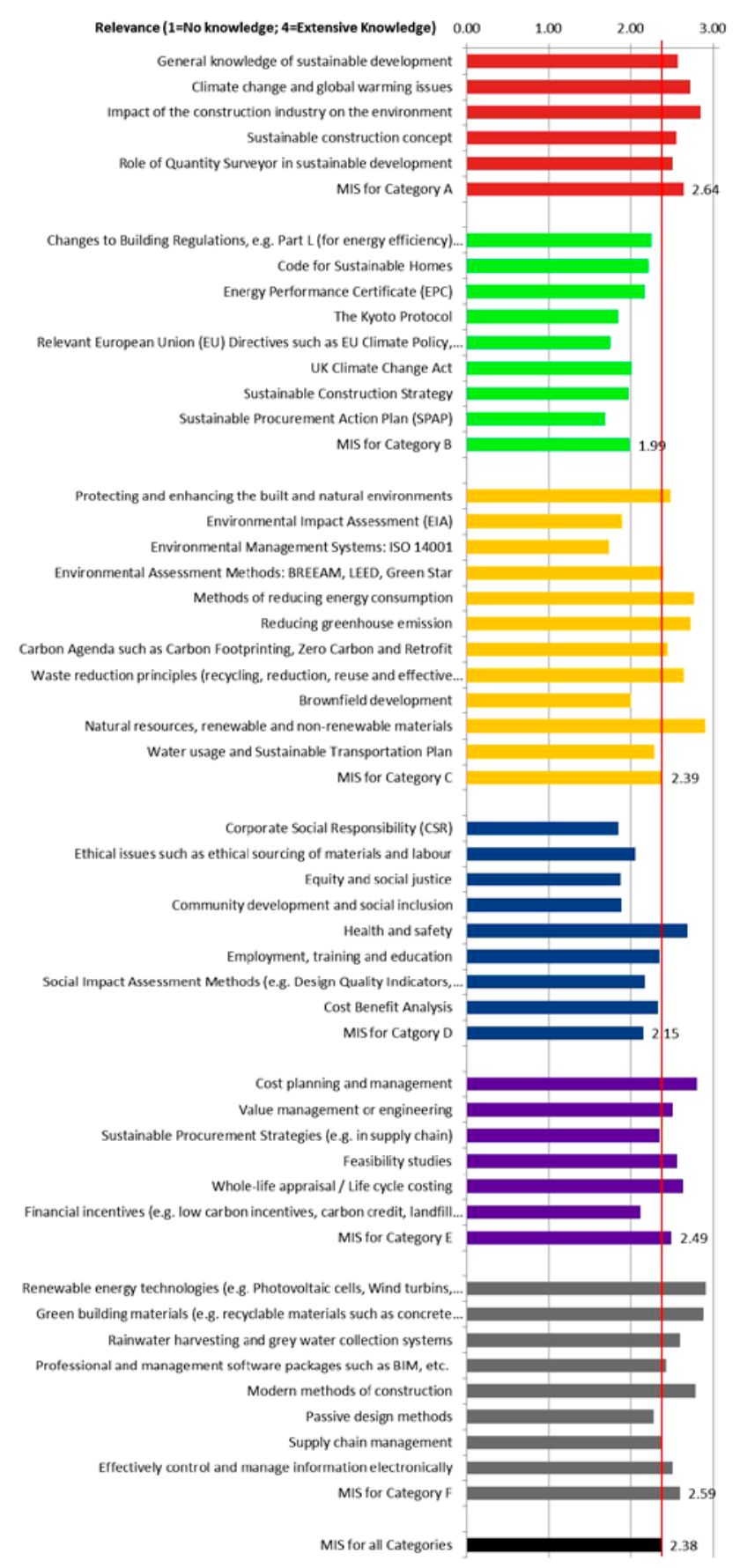

Fig. 2. Students knowledge level on sustainability topics

(see Fig. 2 for details). It can be deduced that students' knowledge level on sustainability was just above "basic/limited knowledge". This indicated that respondents had shown relatively balanced knowledge and understanding of the sustainability topics in this study (see Fig. 2). The reason behind this moderate level of students' sustainability knowledge may be partly due to the fact that the university of the respondents had approached sustainability education in a holistic and balanced way within a relevant context. Moreover, the possibility of respondents gaining knowledge and

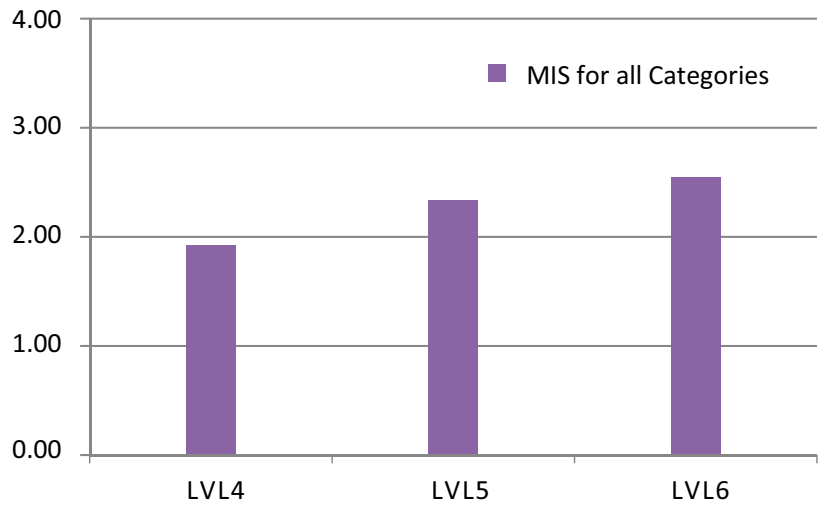

*Note: LVL4-Year 1 in the university; LVL5-Year 2 in the university; LVL6-Final year in the university.

Fig. 3. The knowledge level of students according to their level of study

awareness from sources other than the university must also be taken into account, especially with regard to part-time students who have relevant industry experience.

Based on the respondents' responses, the performance of students at different degree levels in sustainability knowledge was further analysed. Figure 3 presents a gradual increasing trend of knowledge level among students in each sustainability category as they progressed higher in education level.

As shown in Figure 3, the majority of the level 4 students (first-year students) had the lowest knowledge level whilst level 6 students (final year students) had the highest knowledge level on sustainability. To compare the sustainability knowledge level among students from all the levels of study, one-way analysis of variance (ANOVA) and a measure of effect size were carried out. It was found that the differences in the average scores between the three levels of study (see Fig. 3) were statistically significant $(\mathrm{p}=0.000,<0.05)$ and $\eta^{2}$ of $0.54(>0.5)$ suggested that the differences were large. In other words, the students at different levels of the study had a different level of access to sustainability knowledge. This may be explained by the university's role in transferring more sustainability knowledge as students advance to higher education level. Also, other possibilities such as students interests or media influence cannot be disregarded as a contributory factor.

To test the relationship between students' level of knowledge and their level of study, regression test and a measure of effect size were used. The p-value of $0.016(p<0.05)$ showed that the relationship between both variables was statistically significant. The adjusted $R^{2}$ value of 0.852 revealed 
that the relationship was strong $\left(\mathrm{R}^{2}>0.5\right)$ and that $85.2 \%$ of the variation in the level of knowledge could be explained by the year of study. In other words, the results indicate that level of study affects students' sustainability knowledge level. The results suggest that the university has been playing an important role in making education for sustainability a possible goal. It may have been increasingly preparing students to be more sustainability literate as they proceed to a higher level of education. It is important that students, especially final year students are equipped with sufficient sustainability knowledge to enable them pursue and promote the sustainability agenda after graduation.

\subsection{Students' expectation}

This is the final section of the questionnaire, the respondents were asked to give their opinions on the importance of the 6 main sustainability knowledge areas (see Fig. 2 for details). These were then compared with their sustainability knowledge in each of the 6 sustainability knowledge area. The essence of this section of the study is to identify the knowledge gaps and then determine how much more effort is needed by the university to satisfy students' needs. Knowledge gaps were discovered to have existed across all categories based on the MIS. This finding is similar to Azapagic et al. (2005) and Nicolaou and Conlon (2012) where students have no sufficient knowledge and understanding of sustainability. This suggests a need to narrow such gaps by the university. QS Students had the largest knowledge gap in Category B - policies and regulations and the smallest in Category A - background knowledge and concept (see Fig. 2 for details). One of the reasons may be that the university has not focused on teaching Category B as much as Category A or such topics tend to be handled by the professional bodies or government when the students need to be qualified as a member of the professional body. The identification of knowledge gap allows the recognition of the problem source Iyer-Raniga et al. (2010) which in turn can provide the educators with practical guidance on how to narrow knowledge gaps Azapagic et al. (2005). In other words, in this context, to improve the sustainability education within the QS curriculum, teaching should focus more on category B.

Figure 4 shows that the students generally exhibited higher levels of perceived importance on the knowledge of sustainability than their level of knowledge. The majority of the students perceived all categories as "Important" with overall MIS of 3.19 (see Fig. 4 for details).

In the light of students strong support for SD with a lower level of knowledge (see Fig. 4), they were conscious of the importance of gaining sufficient knowledge of sustainability from the university in order to be competent in participating in the SD agenda in the future. This highlights the existence of gaps between students' needs and expectations and their actual experience, which the university will need to address to maintain the practical relevance of their programmes. As pointed out by Kagawa (2007), in the process of embedding sustainability education, students' needs, aspirations, and concerns cannot be ignored. Clearly, these findings revealed that there is room for improvement in the current sustainability education within the QS curriculum. Therefore, students' perceptions of sustainability have offered an understanding of their awareness, attitudes, knowledge and opinion towards sustainability. Although sustainability education has been implemented

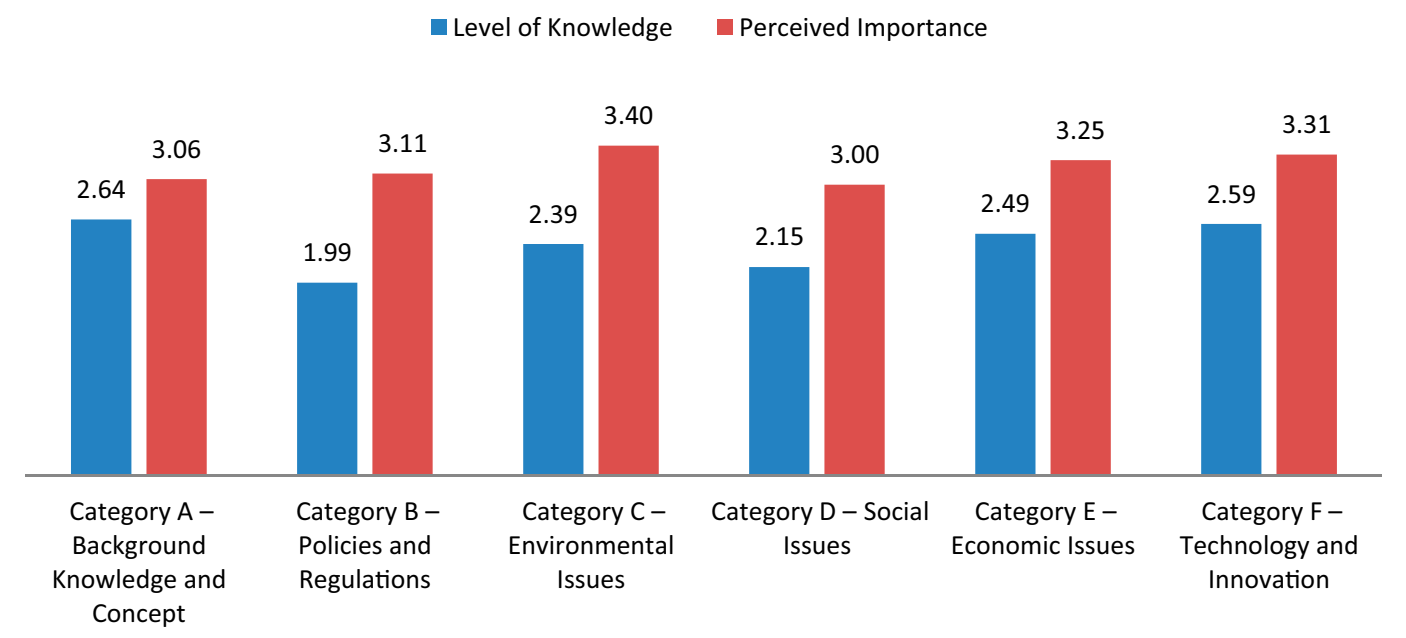

Fig. 4. Students' knowledge level and perceived importance of sustainability categories 
within QS curriculum to a certain extent according to this study, the findings suggest that there is an urgent need to improve the present curriculum to ensure that sustainability education meets the requirements of QS students, as well as to increase their knowledge and influence their behaviour for their future undertakings.

\section{CONCLUSION AND FUTURE RESEARCH}

Sustainable development (SD) has become an inevitable trend in recent years, due to adverse environmental impacts, such as global climate change, degradation of ecological balance and diminution of natural resources. SD has gained its popularity and momentum within the UK and its construction industry through recent heavy government imposed legislations and regulations, increased standards of competencies from professional bodies, and vigorous institutional educations and researchers. The construction industry has been deemed as the prime mover of the economy as well as the main protagonist of SD. Thus, the quantity surveyors as part of the construction industry have an important role to play in order to help to balance out the environmental, economic and social problems caused by the construction industry. This study revealed that the students were aware of the concept of SD and majority of students held positive attitudes towards SD. This demonstrates that the role of the university in bringing awareness of SD to the students is successful and critical. It is also important that the university can nurture their positive attitudes further to enable them to engage in sustainability agenda more whole-heartedly. About the students' knowledge and understanding aspects, the study showed that the implementation of the curriculum has been successful to a certain extent in introducing SD holistically. This study further revealed that students in different years of study had a different level of knowledge and their level of knowledge was strongly related to their year of study. However, knowledge gaps were still found across all categories of sustainability knowledge areas. In particular, the largest gap was found in knowledge about policies and regulations endorsed by the government to promote SD. The study also revealed that the students placed a high importance of sustainability education despite knowledge level were found lower. This study is not without limitation. First, the respondents considered in this study were from only one RICS accredited University in the North East of the UK, considering other RICS accredited universities of- fering Quantity Surveying programme in the UK would have enhanced the credibility of the findings. Second, although the use of questionnaire survey allows the large sample to be captured, having other methods together such as interviews and the use of case study approach may enrich the findings. Despite its limitations, the findings emanating from this study prove to be more reliable as they come about not merely from a library investigation but rather from field work approach which involved getting students shared their true experiences. Thus, future research should be conducted to involve several universities on a periodical basis, and comparisons could be made to monitor the progressions of the curriculum, as well as the students' expectation of the sustainable development. Also, in future surveys, new topics need to be included in line with environmental, technological, governmental, economic and social changes. Similarly, further research is needed to extend or map the sustainability education within other construction related programmes in the HEIs. It might also be useful for the university to conduct a survey to monitor whether knowledge gained by graduates is put into actual practice or is relevant to their working careers.

These study findings revealed room for improvement in the current sustainability education within QS curriculum. Thus, the study recommends that:

- Teachings should focus more on category $\mathrm{B}$ - policies and regulations of sustainability knowledge areas.

- The task of embedding sustainability within QS curricula needs to be supported by a determined institutional ethos and continuously review.

- The university should be innovative and selective in teaching and imparting the knowledge deemed most important and least known to the students.

- Reorienting QS education i.e. there is urgent need to reorient existing QS education policies, programmes and practices so that they build the concepts, skills, motivation and commitment needed for sustainable development.

It is believed that this study would be of great value to academic staff and University management boards to develop a methodology for incorporating sustainability education into their curricula. The professional bodies will also benefit through using the 46 sustainability topics to establish the relevant competencies required for a graduate quantity surveying professional. 


\section{REFERENCES}

Abdul-Wahab, S. A.; Abdulraheem, M. Y.; Hutchinson, M. 2003. The need for inclusion of environmental education in undergraduate engineering curricula, International Journal of Sustainability in Higher Education 4(2): 126-137.

https://doi.org/10.1108/14676370310467140

Azapagic, A.; Perdan, S.; Shallcross, D. 2005. How much do engineering students know about sustainable development? The findings of an international survey and possible implications for the engineering curriculum, European Journal of Engineering Education 30(1): 1-19. https://doi.org/10.1080/03043790512331313804

Bartlett, J. E.; Kotrlik, J. W.; Higgins, C. C. 2001. Organisational research: determining appropriate sample size in survey research, Information Technology, Learning and Performance Journal 19(1): 43-50.

BERR. 2008. Strategy for sustainable construction, department for business, enterprise \& regulatory reform. HM Government in Association with Strategic Forum for Construction, 1-64.

Boardman, B. 2007. Examining the carbon agenda via the $40 \%$ house scenario, Building Research and Information 35(4): 363-378. http://dx.doi.org/10.1080/09613210701238276

Bourdeau, L. 1999. Sustainable development and the future of construction: a comparison of visions from various countries, Building Research and Information 27(6): 355-367. https://doi.org/10.1080/096132199369183

Cartlidge, D. 2011. New aspects of quantity surveying practice. Oxon: Spon Press.

Cortese, A. D. 2003. The critical role of higher education in creating a sustainable future, Planning for Higher Education 31(3): 15-22.

Cotgrave, A. J.; Kokkarinen, N. 2010. Developing a model promoting sustainability literacy through construction curriculum design, Structural Survey 28(4): 266-280. https://doi.org/10.1108/02630801011070975

Cotgrave, A. J.; Kokkarinen, N. 2011. Promoting sustainability literacy in construction students: implementation, Structural Survey 29(3): 197-212. https://doi.org/10.1108/02630801111148185

Cotgrave, A.; Alkhaddar, R. 2006. Greening the curricula with construction programs, Journal of Education in the Built Environment 1(1): 3-29. https://doi.org/10.11120/jebe.2006.01010003

Cowling, E.; Lewis, A.; Sayce, S. 2007. Exploring the changing nature of students' attitudes and awareness of the principles of sustainability, in Proceedings of the Built Environment Education Annual Conference (BEECON 2007): Developing competent people, 12-13 September 2007, London, U.K.

Darwish, M. M.; Agnello, M. F. 2009. Enabling construction engineering students in sustainable thinking: curricular changes to foster sustainability, in Proceedings of the $7^{\text {th }}$ LACCEI Latin American and Caribbean Conference for Engineering and Technology, 2-5 June 2009, San Cristóbal, Venezuela.
Dixon, T.; Colantonio, A.; Siers, D.; Reed, R.; Wilkinson, S.; Gallimore, P. 2008. A green profession? A global survey of RICS Members and their engagement with the sustainability agenda, Journal of Property Investment and Finance 26(6): 460-481. https://doi.org/10.1108/14635780810908352

Drayson, R.; Bone, E.; Agombar, J.; Kemp, S. 2013. Student attitudes towards and skills for sustainable development. The Higher Education Academy, York, U.K.

Edum-Fotwe, F. T.; Price, A. D. F. 2009. A social ontology for appraising sustainability of construction projects and developments, International Journal of Project Management 27: 313-322. https://doi.org/10.1016/j.ijproman.2008.04.003

Ekundayo, D.; Zhou, L.; Udeaja, C.; Pearson, J.; Perera, S. 2011. Mapping of sustainability education to construction related curricula: a case study of quantity surveying (QS) degree programme, in Proceedings of RICS Construction and Property Conference (COBRA 2011), 12-13 September 2011, School of the Built Environment, University of Salford, Manchester, U.K.

Emmanuel, M. R.; Baker, K. 2012. Carbon management in the built environment. London: Routledge.

Ganah, A.; Pye, A.; Hall, G. 2008. The role of knowledge transfer in sustainability research in the built environment discipline, in A. Dainty (Ed.). Proceedings of $24^{\text {th }}$ Annual ARCOM Conference, 1-3 September 2008, Cardiff, UK, Association of Researchers in Construction Management, 299-307.

George, D.; Mallery, P. 2003. SPSS for windows step by step: a simple guide and reference 11.0 update. Boston: Allyn and Bacon.

Gilham, A. V. 2001. Sustainable Buildings, in T. G. Carpenter (Ed.). Environment, construction, and sustainable development. New York: John Wiley and Sons Ltd.

Grubb, M.; Koch, M.; Thomson, K.; Munson, A.; Sullivan, F. 1993. The "Earth Summit" agreements - a guide to assessment, an analysis of the Rio'92 UN Conference on Environment and Development. Earthscan Publications Ltd.

Hanning, A.; Abelsson, A. P.; Lundqvist, U.; Svanstrom, M. 2012. Are we educating engineers for sustainability? Comparison between obtained competences and Swedish industry's needs, International Journal of Sustainability in Higher Education 13(2): 305-320. https://doi.org/10.1108/14676371211242607

Hayles, C. S.; Holdsworth, S. E. 2008. Curriculum change for sustainability, Journal for Education in the Built Environment 3(1): 25-48.

https://doi.org/10.11120/jebe.2008.03010025

Hill, R. C.; Bowen, P. A. 1997. Sustainable construction: principles and a framework for attainment, Construction Management and Economics 15: 223-239. https://doi.org/10.1080/014461997372971

Iyer-Raniga, U.; Arcari, P.; Wong, J. 2010. Education for sustainability in the built environment: what are students telling us?', in C. Egbu (Ed.). Proceedings of $26^{\text {th }}$ Annual ARCOM Conference, 6-8 September 2010, Leeds, UK, Association of Researchers in Construction Management, 1447-1456. 
Kagawa, F. 2007. Dissonance in students' perceptions of sustainable development and sustainability: implications for curriculum change, International Journal of Sustainability in Higher Education 8(3): 317-338. https://doi.org/10.1108/14676370710817174

Kibert, C. J. 2007. The next generation of sustainable construction, Building Research and Information 35(6): 595-601. https://doi.org/10.1080/09613210701467040

Lee, C. C.; Perera, S.; Hogg, K. 2013. An analysis of early career training requirements for quantity surveying professionals, International Journal of Strategic Property Management 17(2): 161-173. https://doi.org/10.3846/1648715X.2013.805450

Lewis, A.; Sayce, S.; Ellison, L. 2005. Education for sustainable development in the built environment disciplines, CEBE Working Paper No. 9. The Higher Education Academy, Centre for Education in the Built Environment (CEBE).

Lozano, R.; Lukman, R.; Lozano, F. J.; Huisingh, D.; Lambrechts, W. 2013. Declarations for sustainability in higher education: becoming better leaders, through addressing the university system, Journal of Cleaner Production 48: 10-19. https://doi.org/10.1016/j.jclepro.2011.10.006

MDG. 2013. Millennium development goals report 2013 [online]. United Nations, New York. Available at: www.Un.org/millenniumgoals/pdf/report-2013/mdgreport-2013-english.pdf [accessed 20 December 2013].

Meikle, J. 2008. UK housebuilding, Building Research and Information 36(2): 200-202.

https://doi.org/10.1080/09613210701841616

Monahan, J.; Powell, J. C. 2011. A comparison of the energy and carbon implications of new systems of energy provision in new build housing in the UK, Energy Policy 39(1): 290-298. https://doi.org/10.1016/j. enpol.2010.09.041

Murray, P. E.; Cotgrave, A. J. 2007. Sustainability literacy: the future paradigm for construction education?, Structural Survey 25(1): 7-23. https://doi.org/10.1108/02630800710740949

Nicolaou, I.; Conlon, E. 2012. What do final year engineering students know about sustainable development? [online]. Arrow@DIT. Available at: http://arrow.dit.ie/engineducart/1/ [accessed 5 October 2012].

Niu, D.; Jiang, D.; Li, F. 2010. Higher education for sustainable development in China, International Journal of Sustainability in Higher Education 11(2): 153-162. https://doi.org/10.1108/14676371011031874

Pellegrini-Masini, G.; Bowles, G.; Peacock, A. D.; Ahadzi, M.; Banfill, P. F. G. 2010. Whole life costing of domestic energy demand reduction technologies: householder perspectives, Construction Management and Economics 28(3): 217-229.

https://doi.org/10.1080/01446190903480027
Perera, S.; Pearson, J. 2011. Alignment of professional, academic and industrial development needs for quantity surveyors: post recession dynamics [online]. RICS Education Trust funded research report. Available at: http://www.northumbria-qs.org/RICS_Alignment/ Reports/Alignment_of_views_final_report.pdf [accessed 29 June 2011].

Perera, S.; Pearson, J.; Ekundayo, D.; Zhou, L. 2013. Professional, academic and industrial development needs: a competency mapping and expert opinion review, International Journal of Strategic Property Management 17(2): 143-160.

https://doi.org/10.3846/1648715X.2013.806966

Revell, A.; Blackburn, R. 2007. The business case for sustainability? An examination of small firms in the UK's construction and restaurant sectors, Business Strategy and the Environment 16(6): 404-420. https://doi.org/10.1002/bse.499

RICS. 2012. Assessment of professional competence [online]. RICS. Available at: www.rics.org/ [accessed 3 January 2013].

Seyfang, G.; Smith, A. 2007. Grassroots innovations for sustainable development: towards a new research and policy agenda, Environmental Politics 16(4): 584-603. https://doi.org/10.1080/09644010701419121

Tan, Y.; Shen, L.; Yao, H. 2011. Sustainable construction practice and contractors' competitiveness: a preliminary study, Habitat International 35(2): 225230. https://doi.org/10.1016/j.habitatint.2010.09.008

Theron, C. 2010. Surveying the sustainable and environmental legal and market challenges for real estate, in Proceedings of RICS COBRA, 2-3 September 2010, Dauphine Université, Paris.

Udeaja, C. E.; Ekundayo, D.; Zhou, L.; Perera, S. 2013. Material waste in the construction industry: a review of the legislative and supply chain issues, in A. Richardson (Ed.). Reuse of materials and by products in construction. London: Springer. https://doi.org/10.1007/978-1-4471-5376-4_2

Walton, S. V.; Galea, C. E. 2005. Some considerations for applying business sustainability practices to campus environmental challenges, International Journal of Sustainability in Higher Education 6(2): 147-160. https://doi.org/10.1108/14676370510589864

Watson, M.; Noyes, C.; Rodgers, M. 2013. Student perceptions of sustainability education in civil and environmental engineering at the Georgia institute of technology, Journal of Professional Issues in Engineering Education Practice 139(3): 235-243. https://doi.org/10.1061/(ASCE)EI.1943-5541.0000156

World Commission on Environment and Development. 1987. Our common future [online]. The World Commission on Environment and Development. Available at: http://www.un-documents.net/ocf-02.htm [accessed 20 April 2015]. 